\title{
ДЕЯТЕЛЬНОСТЬ МОЛОДЫХ ВОЛОНТЕРОВ В СОВРЕМЕННОЙ РОССИИ
}

\author{
С. П. Буриев, Ю. М. Дворянцева \\ (Московский гуманитарный университет)
}

\begin{abstract}
Аннотация: В статье анализируется молодежное волонтерское движение в России; дается характеристика его участникам; описываются причины и побудительные мотивы вовлечения молодых людей в этот процесс, выявляются позитивные и негативные эффекты деятельности волонтеров.

Ключевые слова: волонтеры; волонтерское движение; молодежь; общественные организации; социальная работа; технология социильной работы
\end{abstract}

\section{ACTIVITIES OF YOUNG VOLUNTEERS IN MODERN RUSSIA}

\author{
S. P. Burtsev, Yu. M. Dvoriantseva \\ (Moscow University for the Humanities)
}

\begin{abstract}
The paper examines the youth volunteer movement in Russia by analyzing the structure of its participants and describing the reasons and individual motives for their involvement. Also discussed are the positive and negative effects of volunteering.

Keywords: volunteers; volunteer movement; youth; NGOs; social work; techniques of social work
\end{abstract}

\section{Введение}

В настоящее время Российская Федерация представляет собой страну с высокой концентрацией разнообразных социальных, политических и экономических проблем (Ильинский, 2006, 2012; Крылова, 2009; Сапронов, 2009; Бурцев, 2014). Поиски их решения требуют разработки, апробации и внедрения новых методов политического управления, экономических инноваций и социальных технологий. В социальной сфере в течение нескольких десятков лет идут процессы реформирования здравоохранения, системы социальной защиты и поддержки граждан страны. Неоднозначные и весьма часто незавершенные преобразования социального 
сектора, уменьшение его реального финансирования, кадровые проблемы вынуждают его руководителей различных уровней изыскивать новые организационные формы деятельности. Одним из весомых направлений этой деятельности объявляется волонтерство. В «Социологической энциклопедии» 2003 г. оно определяется как «добровольное принятие обязанностей по оказанию безвозмездной социальной помощи, услуг, патронажа над инвалидами, больными и престарелыми, а также над лицами и социальными группами населения, находящимися в сложных жизненных ситуациях» (Социологическая энциклопедия, 2003: 163).

Изначально в России и других странах волонтерская деятельность осуществлялась в рамках общественных организаций: религиозных, экологических и других. Она подразумевала осознанную, бескорыстную, сформированную на основе идеологии данной организации потребность оказывать помощь социально незащищенным гражданам.

В последние годы понятие «волонтер» стала распространяться и на другие сферы общественной деятельности. Так, волонтерами называют молодых людей, помогающих организационным комитетам в проведении Олимпийских игр, чемпионатов мира и других крупных соревнований. Однако, в данном примере отсутствует объект волонтерской помощи, т. к. перечисленные мероприятия являются весьма крупными бизнес-проектами, в которых заняты профессиональные спортсмены, представляющие одну из самых богатейших категорий населения планеты. И, наоборот, в деятельности ряда государственных и образовательных структур встречаются элементы истинной волонтерской работы (Бурцев, 2014; Сикорская, 2006, 2009). Так, в 1960-1980-х гг. в учебных планах лечебных факультетов медицинских институтов были предусмотрены вечерние дежурства в клиниках кафедр детских болезней. Основное время таких дежурств проходило в неформальном общении студентов с больными детьми, которые были вынуждены длительное время находиться вдали от дома. По свидетельству самих больных детишек, для них это были самые счастливые часы. По своей сути это была самая настоящая волонтерская работа.

Таким образом, можно отметить, что смысловая и технологическая граница между волонтерством и общественной работой не является четкой.

Однако, на наш взгляд, это не принципиально в контексте существенной позитивной социальной значимости обоих процессов.

\section{Кадровый состав российского волонтерского движения}

Основное ядро волонтерского движения составляют студенты высших учебных заведений, действующих либо в рамках общественных молодежных организаций, либо при реализации молодежных социальных проек- 
тов. Можно отметить, что среди студентов всех факультетов Московского гуманитарного университета всегда находится много желающих сдать донорскую кровь (проекты «Подари жизнь» и «Мы с тобой одной крови»). Также необходимо отметить высокую активность студенческой молодежи в нормализации очень сложной экологической ситуации в Москве. В частности, за последние годы существенно улучшилось состояние московских парков, садов и бульваров. Важную роль в этом играют студенты и школьники, занимающиеся очисткой парков от мусора, высаживанием цветов, кустарников и деревьев, сохранением животного мира.

Названные выше два вида волонтерской деятельности наиболее заметны и эффективны, т. к. направлены на оказание социальной помощи практически всем жителям города Москвы. По свидетельству депутатов Мосгордумы, курирующих медико-социальную работу в городе, донорская кровь, сданная волонтерами, полностью удовлетворяет потребности в ней у жителей и гостей Москвы.

Вторую, также большую по численности группу волонтеров, составляют студенты гуманитарных факультетов учреждений высшего образования, проходящие различные виды практики (Клушина, 2004).

Приобретенные теоретические знания и руководство супервайзерами позволяют им весьма позитивно работать даже с теми социальными группами (например, дети, тяжелобольные пациенты, старики), в которых формируются медицинские и социальные проблемы, требующие специальных знаний обслуживающего персонала (Рогов, 2000; Горянина, 2002). Нередко знакомство с людьми, нуждающимися в помощи и поддержке, оставляет стойкий эмоциональный и психологический след в душе молодого студента. Нам известно несколько случаев, когда студенты факультета социальной работы после посещения детского дома, в котором воспитывались дети первого года жизни, продолжали посещать их во внеучебные часы в течение долгого времени, а также делали попытки усыновления.

Третью группу составляют молодые люди (главным образом, молодые мамы), родившие больного ребенка. Наиболее часто это наблюдается в семьях, где новорожденный имеет диагноз наследственной или врожденной патологии. Находя соратников по несчастью в электронных информационных сетях, такие родители обмениваются информацией по разным аспектам проблемы: выбору лечебно-профилактического и реабилитационного учреждения, технологиям медико-социальной экспертизы, использованию лекарственных препаратов и многим другим. В МосГУ обучалось несколько студенток, относящихся к описываемой группе. Поводом поступления в вуз явилось понимание нехватки знаний и практического опыта в подобной деятельности. В некоторых случаях это 
было началом работы по созданию частных специализированных реабилитационных центров.

К четвертой группе относятся «одиночные» волонтеры. В частности, по результатам многолетних исследований кафедры социологии МосГУ среди первокурсников, обучающихся по направлению «психология» встречаются молодые люди, имеющие психологические проблемы. Они догадываются о присутствии психологических расстройств и обучаются в вузе с целью их устранения. При этом студенты часто самостоятельно берутся за исполнение волонтерских функций, даже не имея для этого необходимого опыта (Фирсов, 2009). Как правило, такая деятельность не бывает продолжительной, а в ней присутствует элемент самоутверждения и достижения превосходства над сокурсниками.

Представителей пятой группы можно обозначить как «потенциальные» волонтеры. Их участие необходимо при ликвидации последствий природных или техногенных чрезвычайных ситуаций, во время поисков пропавших граждан (особенно детей), например заблудившихся в лесах, в туристических походах, горах и т. д. Весьма полезно, с этой точки зрения, то, что изучение дисциплины «Безопасность жизнедеятельности» является обязательным в школах и высших учебных заведениях. Практическая направленность этой дисциплины позволяет довольно быстро организовать работу в условиях реальной опасности. Волонтерство уже присутствует в виде спасения на водоемах и оказания вспомогательной противопожарной помощи.

Возможно, что в последующем подробном исследовании мотивационных установок волонтерской деятельности выявятся и иные причины. Не исключается, что их может быть достаточно много.

\section{Факторы, влияющие на волонтерскую деятельность}

Факторы, определяющие объем и качество волонтерской деятельности в обществе, условно можно разделить на две группы. Первая - это отказ государства от социальных обязанностей по поддержке социально незащищенных групп и поиск руководителями различных уровней бесплатных технологий путем привлечения студентов, школьников или представителей церкви; вторая - появление в обществе условий для повсеместного распространения духовных ценностей и свободного времени у молодежи.

С 2007 г., когда был принят закон «О монетизации льгот», положение социально незащищенных категорий граждан в РФ стремительно ухудшалось. Перманентная реформа пенсионной системы не позволила приостановить развитие социального кризиса. Последующая «оптимизация», проводимая в органах социальной защиты, системе здравоохра- 
нения, образовательной сфере, а также нарастание налогового бремени на население явились важным побудительным мотивом использования бесплатной волонтерской помощи. Однако, всячески поощряемая всеми государственными структурами установка на «самовыживаемость» предприятий, фирм, семей и отдельных граждан вошла в противоречие с самой идеей волонтерской работы. Еще один аспект этой проблемы имеет идеологическое значение. Он обусловлен колоссальной разницей в материальном положении между 10\% самых богатых граждан и остальным населением России. Именно к той части населения, которая живет в районе прожиточного минимума, обращены призывы участвовать в волонтерской деятельности. К сожалению, учащаяся молодежь (до 95\% всех студентов разных курсов обучения) вынуждена сама работать и поэтому практически не имеет свободного времени для продолжительного исполнения волонтерских функций (Бурцев, 2013; Бурцев, Дворянцева, Солодилова, 2014).

К великому сожалению, не может быть реализована в современной России вторая группа факторов. Школа утратила свое образовательное и воспитательное значение, превратившись в очень крупный бизнеспроект, направленный только лишь на получение высокого рейтинга при сдаче Единого государственного экзамена молодыми людьми, а семья не занята воспитанием, т. к. занимается «выживанием». Идеологически сформированный в России культ денег и силы по определению не приемлет безвозмездную волонтерскую помощь.

Таким образом, в Российской Федерации главным побудительным мотивом волонтерской деятельности является неудовлетворенная потребность нуждающихся в социальной помощи, а не духовная потребность молодых людей ее оказывать.

\section{Положительные и отрицательные последствия волонтерской деятельности}

Тщательно спланированная и организованно проведенная подготовленным волонтером социальная работа позволяет решить многие проблемы граждан, оказавшихся в трудной жизненной ситуации. Однако, в недавнем прошлом, в частности в 1970-1980-х гг., резкая активизация общественных бесплатных спортивных кружков, которыми руководили молодые инструкторы (фактически - волонтеры) позволила создать на их основе многочисленные организованные преступные группы, явившиеся действующей силой (наряду с работниками силовых структур) криминального преобразования России.

Изначальной идеей этого губительного процесса были установки государства на улучшение физического здоровья, отказа от вредных привычек 
и формирование в стране здорового образа жизни. В наши дни примером похожего отрицательного результата социальной добровольной работы с одинокими пожилыми людьми, владеющими квартирами, явился договор ренты на жилплощадь. По причине высокой криминогенной опасности эта работа была запрещена правоохранительными органами.

Волонтерская деятельность представителей Русской православной церкви и других конфессий мало обсуждается в специальной литературе и средствах массовой информации. Ей очень трудно дать однозначную оценку, в том числе из-за использования церковью технологий для достижения большего политического и идеологического влияния в России, а также стремительного наращивания своей экономической деятельности.

Волонтерская работа с детьми, пожилыми людьми, тяжелобольными и лицами, со сформированной социальной патологией должна проводиться весьма осторожно и аккуратно. Волонтеры не являются специалистами в социальной работе. Поэтому их деятельность может сопровождаться неудачами и ошибками. Начинающие волонтеры не имеют навыков психологического общения с указанными категориями граждан, могут стать жертвами обмана и насилия со стороны лиц с криминальным прошлым и настоящим (Панкратов, 2001).

В целом, волонтерская работа в этих случаях имеет крайне низкую эффективность и результативность. Так, например, сопровождение стариков или тяжелобольных граждан может осуществляться в виде его траспортировке на автомобиле, если он имеется у молодого волонтера. А выполнение простейших функций по уходу за больным или его жилищем лучше предоставить профессиональной сиделке, нянечке или санитарке (Валентик, Новиков, Булатников, 2008; Цейтлин, 2012).

Однако, если волонтер поступательно развивается во время обучения в вузе, отслеживает инновационные методики социальной работы, наращивает свой культурный и правовой уровень знаний, то произойдет главное: переход от волонтерской работы к профессиональной (Усманов, 2007).

\section{Социальные и медико-социальные технологии в волонтерской деятельности}

Волонтерство весьма гармонично вписывается в содержание и формы медико-социальной работы с населением. Известно, что медикосоциальная работа - это практическая деятельность медицинского, социально-правового и психолого-педагогического характера, направленная на восстановление, сохранение и укрепление здоровья граждан. В рамках медицинского направления волонтерство успешно реализуется в социальных проектах по сбору донорской крови. Причем, молодые волонтеры не только являются донорами крови, но и выступают в после- 
дующем как активные пропагандисты этого важного дела. Вторая технология медицинского направления реализуется путем формирования и распространения здорового образа жизни.

Необходимо отметь, что данная работа должна проводиться не только с детьми, но и с родителями. Сегодня большинство мам и пап хотят видеть своего ребенка профессиональным спортсменом, получающим высокие гонорары: теннисистом, футболистом или хоккеистом. Давно доказано, что профессиональный спорт разрушает здоровье путем обязательного использования допинга, нервно-физическими перегрузками, отсутствием настоящей дружбы между спортсменами и др. Формировать здоровый образ жизни наиболее эффективно в общих группах, которые все вместе занимаются на открытом воздухе в парках и скверах Москвы.

Волонтерская работа, осуществляемая на стыке медицинского и социально-правового направлений - это многообразные экологические акции по приведению окружающей среды в достойный вид, социальные и политические действия по разработке и исполнению законодательства в этой сфере. После проведения таких начальных мероприятий волонтеров можно подключать к экологическому просвещению и образованию, которые ставят своей целью воспитание экологического мировоззрения. Экологическое образование в широком смысле способно объединить нацию, весь мир вокруг общих ценностей.

Волонтерская деятельность в социально-правовой и психологопедагогической направленности заключается в создании особого электронного пространства или социальной сети, предназначенной для категорий лиц, оказавшихся в трудной жизненной ситуации. В этой области волонтеры могут трудиться совместно с социальными работниками (Гуслякова, Холостова, 1997; Дементьева, 2010).

При этом можно использовать знания молодых волонтеров в области электронных технологий, им можно поручить обучение пожилых людей или больных работе с электронным устройством. Таким образом могут решиться две важнейшие проблемы пожилых людей: получение достоверной информации, касающейся их здоровья и социального благополучия, а также поучение возможности общения с родными, знакомыми и сверстниками.

\section{Заключение}

Деятельность волонтерских объединений, групп и отдельных участников наиболее эффективно может быть реализована в следующих направлениях:

- в проведении массовых медицинских мероприятиях (сдача крови, ее компонентов, плазмы и др.);

- в проведении экологических акций, осуществлении экологического 
просвещения и образования и, в конечном итоге, в формировании экологической культуры населения;

- в формировании здорового образа жизни и, как следствие этого - в улучшении физического и психического здоровья населения;

- в создании особого информационного пространства для интернетобщения пожилых людей.

«Потенциальная» волонтерская работа может быть успешно реализована в различных чрезвычайных ситуациях природного и техногенного характера при качественной подготовки школьников и студентов по учебной дисциплине «Безопасность жизнедеятельности».

\section{СПИСОК ЛИТЕРАТУРЫ}

Бурцев, С. П. (2013) Массовое образование: образовательные и информационные технологии социальной работы с молодежью в области иммунопрофилактики. М. : Изд-во Москов. гуманит. университета.

Бурцев, С. П., Дворянцева, Ю. М., Солодилова, Н. Ю. (2014) Сексуальное образование в современной России. // Высшее образование для XXI века: XI Международная научная конференция. Москва, 27-29 ноября 2014 г. : Доклады и материалы. Секция 2. Социология образования / отв. ред. Н. А. Селиверстова. М. : Изд-во Моск. гуманит. ун-та. С. 17-27.

Бурцев, С. П. (2014) Безопасность жизнедеятельности. М. : МосГУ.

Бурцев, С. П. (2014) Социальная медицина М. : Юрайт.

Валентик, Ю. В., Новиков, Е. М., Булатников, А. Н. (2008) Медикосоциальная работа в наркологии. М. : Изд-во Москов. гуманит. ун-та.

Горянина, В. А. (2002) Психология общения. М. : Академия.

Гуслякова, Л. Г., Холостова Е. И. (1997) Основы теории социальной работы. М. : Юрист.

Дементьева,Н.Ф.(2010) Социальная работа в учреждениях социальнореабилитационного профиля и медико-социальной экспертизы. М. : Академия.

Ильинский, И. М. (2006) Между будущим и прошлым : социальная психология происходящего. М. : Изд-во Москов. гум. унив-та.

Ильинский, И. М. (2012) Выбор России: об итогах выбора Президента Российской Федерации 2012 года // Знание. Понимание. Умение. № 2. С. 3-9.

Клушина Н. П. (2004) Организация практики студентов по социальной работе. М. : ВЛАДОС.

Крылова, И. А. (2009) Социальная модернизация и кризисные процессы в России // Знание. Понимание. Умение. № 4. С. 56-62.

Панкратов, В. Н. (2001)Манипуляции в общении и их нейтрализация. М. : Изд-во института психотерапии.

Рогов, Е. Н. (2000) Психология общения. М. : ВЛАДОС. 
Сапронов, В. В. (2009) Безопасность жизнедеятельности. М. : Поколение.

Сикорская, Л. Е. (2006) Волонтерство как фактор формирования гуманистической направленности личности студента в современном обществе // Знание. Понимание. Умение. № 1. С. 211-213.

Сикорская, Л.Е. (2009) Волонтерство как форма трудового воспитания студенческой молодежи // Знание. Понимание. Умение. № 1. С. 163-168.

Социологическая энциклопедия (2003) : в 2 т. / рук. проекта Г. Ю. Семигин. М. : Мысль. Т. 1.

Усманов, Б. Ф. (2007) Социальная инноватика. М. : Социум.

Фирсов, М. В. (2009) Психология социальной работы: содержание и методы психосоциальной практики. М. : Академия.

Цейтлин, Г. Я. (2012) Медико-социальная работа в онкологии. М. : Изд-во Москов. гуманит. университета.

Бурцев Сергей Петрович - кандидат медицинских наук, доцент, профессор кафедры социологии Московского гуманитарного университета. Адрес: 111395, Россия, г. Москва, ул. Юности, д. 5. Тел.: +7 (499) 374-60-21. Эл. адрес: sergei-burcew@mail.ru

Дворянщева Юлия Михайловна - кандидат медицинских наук, доцент, доцент кафедры социологии Московского гуманитарного университета. Адрес: 111395, Россия, г. Москва, ул. Юности, д. 5. Тел.: +7 (499) 374-60-21. Эл. адрес: socio-mosgu@mail.ru

Burtsev Sergei Petrovich, Candidate of Medicine, Professor, Department of Sociology, Moscow University for the Humanities. Postal address: 5 Yunosti St., 11395 Moscow, Russian Federation. Tel.: +7 (499) 374-60-21. Email: sergeiburcew@mail.ru

Dvoriantseva Yulia Mikhailovna, Candidate of Medicine, Professor, Department of Sociology, Moscow University for the Humanities. Postal address: 5 Yunosti St., 111395 Moscow, Russian Federation. Tel.: +7 (499) 37460-21.Email: socio-mosgu@mail.ru 